\title{
THE SERBIAN HISTORIOGRAPHER AND POET, JOVAN RAICH ${ }^{1}$
}

\section{Abstract:}

The article talks about the life and work of a prominent figure of the South Slavic national revival, historiographer, poet and translator Jovan Raich (1726-1801), one of the most educated Serbs of his era. He studied in many countries, spoke five foreign languages, left behind a solid original and translated creative heritage. The most significant of his writings was the voluminous historiographical work The History of different Slavic peoples, primarily of the Bulgarians, Croats and Serbs..., published at the end of the 18th century in Vienna and St. Petersburg. For his works he earned awards from the Austrian and Russian Empresses. Equally striking was Raich's contribution to the development of national Serbian poetry. Unlike the historiographical writings that Raich wrote in Russian-Church-Slavic, he used a language close to the living Serbian spoken language in his poems.

\section{Keywords:}

South Slavic national revival, historiography, Serbian writer from Voyvodina, "The History of different Slavic peoples, primarily of the Bulgarians, Croats and Serbs...", religious and secular enlightenment.

АННОТАЦИЯ: И.И. КАЛИГАНОВ. «СЕРБСКИЙ ИСТОРИОГРАФ И ПОЭТ ЙОВАН РАИЧ».

В статье рассказывается о жизни и творчестве видного деятеля южнославянского национального возрождения, историографа, поэта и переводчика Йована Раича (1726-1801) - одного из самых образованных сербов своей эпохи. Он учился во многих странах, владел пятью иностранными языками, оставил после себя солидное оригинальное и переводное творческое наследие. Наиболее значительным среди него был объемный историографический труд «История разных славянских народов, наипаче Болгар, Хорватов и Сербов..., изданный в конце XVIII столетия в Вене и Санкт-Петербурге. За свои труды он заслужил награды от австрийской и российской императриц. Не менее ярким был вклад Раича и в развитие национальной сербской поэзии. В отличие от историографических сочинений, которые Раич писал на русско-церковно-славянском языке, в своих стихах он использовал язык, близкий к живому сербскому разговорному.

\section{Ключевые слова:}

Национальное возрождение у южных славян, историография, сербский писатель из Воеводины, «История разных словенских народов, наипаче болгар, хорватов и сербов», религиозное и светское просветительство.

Tovan Raich is an outstanding figure of the South Slavic national revival, widely known in the Orthodox Slavic world, a Serbian writer, poet, translator, historiographer and author of the famous The History of different Slavic people primarily of the Bulgarians, Croats and Serbs... He was born into a poor

\footnotetext{
1 The work was carried out with the financial support of the RFBR (grant № 18-512-76004).
} 
family in Sremski Karlovtsi in Voyvodina, a Serbian city that was ceded to Austria after the 1688-89 war with the Ottoman Empire and became the religious center of the Orthodox Austrian Serbs. It was here that the residence of the Metropolitan was located, and subsequently the first Serbian gymnasium (1791) and seminary (1794) were opened. Jovan received a basic education at the school from Deacon P. Raikovich and the Latin-Slavic School of the Nativity of the Virgin, where Emmanuel Kozachinsky, a native of Russia, taught, and then from 1774 he studied at the Jesuit gymnasium of Komarom and the Protestant lyceum of Sopron. During his years of study, he mastered Latin, Church Slavonic, Russian, German and Hungarian. Desiring to further improve his education, Raich set out on foot to Russia, where he studied at the Kievo-Mogyla Academy from 1753 to 1756.

After graduating from this institution, Raich traveled extensively, visiting Moscow, Smolensk, Poland, Moldova, Walachia, Constantinople and Mount Athos. Then he devo-

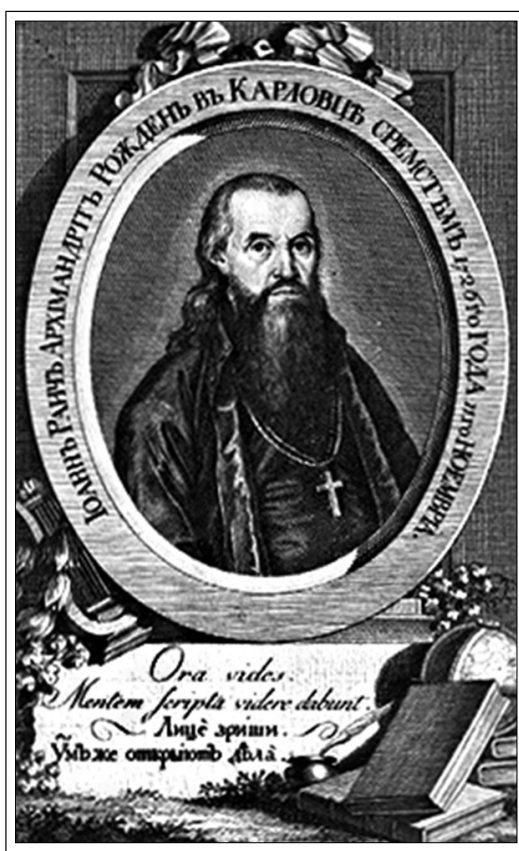

Jovan Raich. Archimandrite. Engraving from the St. Petersburg edition of The History of different Slavic Peoples, 1795 ted himself to pedagogical work: from 1759 to 1762 he was a teacher of geography and rhetoric and then the rector of the School of the Intercession of the Virgin in Sremski Karlovtsi. Some years later, at the invitation of the Bishop of Bachka, Moses Putnik, he arrived in Novi Sad, where for five years he taught theology as a professor at the Theological Academy (collegium), serving at the same time as its rector. During this period and later, he was engaged in translating from Church Slavonic and German. Most of the works he translated were on spiritual and religious themes and were written by such Ukrainian and Russian authors as Theophan Prokopovich, Peter Mogyla, Metropolitan Platon (Levshin) and Lazarus Baranovych. Raich's translation of the secular drama, Urosh V ("The Tragedy of King Urosh"), written by his teacher, E. Kozachinsky, should also be noted.

The last period of Raich's life was connected with monastic life: in 1772 he took monastic vows in the ancient monastery of the Holy Archangels (founded by St Sava of Serbia) in the village of Kovil near Novi Sad. Subsequently, he was quickly ordained as a hieromonk and then placed in the archimandrites and became a hegemon of the monastery until the end of his days. During this period, he wrote the first history of the Serbian church and published the Small Catechism. 
Raich combined his pedagogical and translation activities with work on the realization of his plan from much earlier to write the history of the Slavic peoples. During his travels, Raich persevered in collecting the materials he needed for this purpose. His stay on Athos and work in the monastery of Hilandar was very fruitful for him; there he not only found many useful documents but also, apparently, met with the leader of the Bulgarian national revival, Paisius of Hilandar, who later wrote his epochal Slavo-Bulgarian History.

According to Raich, he completed his historical work on the Slavs in 1768 but continued to refine it for more than a quarter of a century. The full title of the work was The History of different Slavic peoples, primarily of the Bulgarians, Croats and Serbs, who were removed from the darkness of oblivion and brought into the light of history by the archimandrite Jovan Raich in the Holy Archangel monastery of Kovil. This massive work of his was first published in Vienna in two installments: books $1-3$ in 1794 and book 4 in 1795. The first was an introduction, and the second was devoted to the history of the Bulgarians and covered the historical period from its origins to the end of the 14th century, i.e., before the conquest of the Second Bulgarian Tsardom by the Turks, as well as a brief history of the Croats. The remainder of the books contained a detailed account of the history of the Serbs and Serbia prior to the Peace of Belgrade in 1739 and the abolition of the Patriarchate of Pech by the Turks.

Working on this, Raich managed to free himself from many medieval principles of scrutinizing historical sources and to come close to the academic methodology of modern times. He divided his work into books, chapters and paragraphs, provided it with the family trees of the ruling dynasties, chronological tables, maps and many other supporting materials, and came close to the method of a critical analysis of historical sources. However, his conclusions were often dictated by feelings of patriotism or confessional (Orthodox) predilections, and some parts of his work have a compilatory or even biased, pro-Serbian character.

The author undoubtedly deserves credit for introducing Serbian historical sources into academic research.

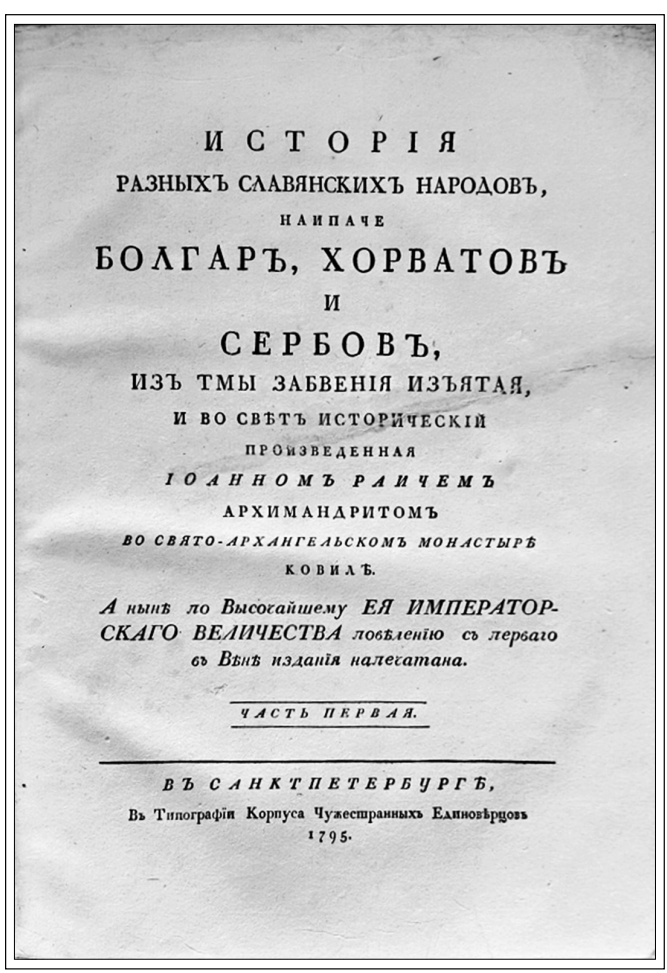

The title page of the work The History of different Slavic Peoples. St. Petersburg, 1795 
Raich's rejection of previous ideas about the linearity and immutability of historical time was also innovative for the Serbs: the author divides it into ancient, medieval and modern eras. The primary manifestation of Raich's "The History..." were the ideas of the unity of the enslaved Southern Slavs, the cult of education and science - "the pillars and ornamentation of a state," the sense of pride in the Slavic historical past. This book had a great impact on the awakening of the national consciousness of the Southern Slavs and the development of their historical thought. For Serbs, it remained a reference book and the main academic source on their national history until the 1860s.

It was of no less importance for the Bulgarians, where, from 1762 onward Paisius of Hilandar's Slavo-Bulgarian History, a work similar in its ideological orientation, was distributed around the country as a handwritten manuscript: the first fragments from it appeared in print only in 1844. But in Russia Raich's afore mentioned work, for obvious reasons, was published almost immediately after the Vienna edition. The first edition was published in St. Petersburg in 1795 and aroused great interest among Russian readers. This was not surprising, since in it readers found many vivid passages telling about the conquest of the Balkan lands by the Slavs and Bulgarians and the creation of a powerful medieval state there, about the legends and historical narratives associated with the baptism of Bulgaria and the "golden" age of the Bulgarian Tsar Simeon, about the Bulgarians' falling under Byzantine rule, the revival of Bulgarian statehood and the arrival of the Turks in the Balkans at the end of the 14th century, and the fall of the Bulgarian Tsardom. Raich proved to be an excellent storyteller, who knew how to interest the reader with the vividness of his narrative and who was able to look at the same event through the eyes of many historians, weighing the reliability of their opinions and the correct choice of perspective. Unfortunately, for reasons of censorship, the publication of the second part of Raich's "The History" was not carried out in Russia. The work of the famous Serbian historiographer was afterwards published in its entirety in Budim (Buda) in 1823.

Raich's contribution to the development of Serbian national poetry in the genre of spiritual poems, epitaphs and historical poems was no less significant. He began to write these starting in the 1790s Pjesni razlicnija ("Various verses", Bech, 1790). The most vivid mark in the history of Serbian literature was left by his historical and allegorical poem, Boj zmaja sa orlovi ("The Fight of the Snake with the Eagles," Bech, 1791), written in Vienna at the height of the AustroRussian-Turkish War (1788-90) and dedicated to the historical event of Belgrade's temporary liberation. Unlike "The History...," which was written in the Russo-Church Slavonic language, the poet turned to the Serbian folk language in the poem. In it, the influence of the Baroque tradition of the Kiev literary school is noticeable. Realistic depictions in the poem are intertwined with mythological and allegorical images: the "Snake" represents the Ottoman Empire, and the "Eagles," Russia and Austria. The solemn tone with respect to the winners is juxtaposed against the mockingly humorous tone in relation to the enemy. There 
is also a "third," hidden character in the poem: the enslaved Serbs, who, having joined the allied armies, are fighting for their freedom. The patriotism, civic spirit, and closeness to the people's aspirations that emerged in Raich's work became the hallmarks of the subsequent development of Serbian poetry.

Raich's achievements in the development of Serbian culture and national spiritual enlightenment were celebrated by Russian Empress Catherine II with a gold medal with her own image, and the Austrian Empress Maria Theresa with a precious Archimandrite's cross. Raich's achievements have not been forgotten in our time either: the name of Jovan Raich is widely known not only in Serbia but also abroad.

Translated by the author

\section{BIBLIOGRAPHY}

Jovan Rajić - život i delo. Belgrade, 1997.

Jovan Rajić - istoričar, pesnik i crkveni velikodostojnik. Zbornik radova. Novi Sad, 2002.

Erchich V. O poeme Iovana Raicha "Boi zmeia s orlami" // Russko-serbskie literaturnye sviazi XVIII-XIX v. Moscow, 1989.

Kaliganov II. Drevnie bolgary v "Istorii raznykh slavianskikh narodov" Iovana Raicha // Rol' Rossii v rasprostranenii znanii o slavianstve. Moscow, 2019. S. 182-223.

\section{ILLUSTRATIONS}

1. Jovan Raich. Archimandrite, engraving from the St. Petersburg edition of The History of different Slavic Peoples. 1795.

2. Jovan Raich, engraving of the 19th century. State Historical Museum, Moscow.

3. Kievo-Mogyla Academy (1659-1817).

4. Mount Athos, monastery of Hilandar.

5. The title page of the work The History of different Slavic Peoples. St. Petersburg, 1795.

6. Monastery of St Archangels in Kovil near Novi Sad, where Raich was tonsured, labored and buried.

7. Contents of the Second Book "On the Bulgarian People" in The History of different Slavic Peoples by Jovan Raich.

8. A large gold medal depicting the face of Catherine II, by whom Raich was honored for his services. 